\title{
ArcheoSciences
}

Revue d'archéométrie

\section{Precious metals determination in ancient coins by portable ED-XRF spectroscopy with a ${ }^{238} \mathrm{Pu}$ source}

Détermination des métaux précieux dans les monnaies anciennes par spectroscopie ED-XRF portable avec une source de ${ }^{238} \mathrm{Pu}$

Paulo S. Parreira, Carlos R. Appoloni, Rejane Maria Lobo Vieira, Rosa B. Scorzelli, Laetitia Le Corre and Maria Filomena Guerra

\section{(2) OpenEdition}

\section{Journals}

Electronic version

URL: http://journals.openedition.org/archeosciences/2396

DOI: 10.4000/archeosciences.2396

ISBN: 978-2-7535-1598-7

ISSN: $2104-3728$

\section{Publisher}

Presses universitaires de Rennes

\section{Printed version}

Date of publication: 31 December 2009

Number of pages: $313-318$

ISBN: 978-2-7535-1181-1

ISSN: 1960-1360

\section{Electronic reference}

Paulo S. Parreira, Carlos R. Appoloni, Rejane Maria Lobo Vieira, Rosa B. Scorzelli, Laetitia Le Corre and Maria Filomena Guerra, « Precious metals determination in ancient coins by portable ED-XRF spectroscopy with a ${ }^{238} \mathrm{Pu}$ source », ArcheoSciences [Online], 33| 2009, Online since 10 December 2012, connection on 01 May 2019. URL : http://journals.openedition.org/archeosciences/2396 ; DOI : 10.4000/archeosciences.2396 


\title{
Precious metals determination in ancient coins by portable ED-XRF spectroscopy with a ${ }^{238} \mathrm{Pu}$ source
}

\author{
Détermination des métaux précieux dans les monnaies anciennes par spectroscopie \\ ED-XRF portable avec une source de ${ }^{238} \mathrm{Pu}$
}

\author{
Paulo S. Parreira*, Carlos R. Appoloni*, Rejane M. Lobo Vieira**, \\ Rosa B. Scorzellit ${ }^{* * *}$, Laetitia Le Corre*** and Maria Filomena Guerra****
}

\begin{abstract}
A portable X-ray fluorescence system (pXRF) was employed to analyse a set of gold, silver and billon coins from the collection of the Museu Histórico Nacional do Rio de Janeiro (MHN), struck during the Brasil Colônia period, under the Dutch occupation, and in Portuguese mints under the reigns of Fernando I (1367 to 1383) and his successor João I (1383 to 1433). The experimental setup consisted of a mini Si-PIN detector and a radioactive source of ${ }^{238} \mathrm{Pu}$ for the excitation of the samples. The aim of the study was to test the possibilities and limitations of this portable system for the determination of the coins' base alloys, and to verify whether the results obtained were consistent with historical facts. The Brasil Colônia period coins show about $80.5 \%$ gold and $96.8 \%$ silver. For the Portuguese coins, we could identify a possible monetary debasement during the reign of João I. No matrix corrections were made for these preliminary results.
\end{abstract}

Résumé : Un équipement portable à fluorescence $X(p F X)$ a été utilisé pour l'analyse de monnaies en or, en argent et en billon appartenant à la collection du Museu Histórico Nacional de Rio de Janeiro (MHN). Certaines de ces monnaies ont été frappées au Brésil pendant la période Brasil Colônia et sous l'occupation hollandaise, alors que d'autres ont été frappées au Portugal sous les règnes de Ferdinand I (1367-1383) et de son successeur Jean I (13831433). Le montage expérimental est constitué d'un mini détecteur Si-PIN et d'une source radioactive de ${ }^{238} \mathrm{Pu}$, dont la radiation émise est utilisée comme source d'excitation. Le but de ce travail est double : vérifier les possibilités et les limites de ce système portable lors qu'il s'agit de déterminer les alliages constitutifs de monnaies en métal précieux et vérifier les rapports entre l'évolution des compositions des monnaies et les différents faits historiques. Les monnaies appartenant à la période Brasil Colônia sont constituées de 80,5\% d'or et de 96,8\% d'argent et les monnaies frappées au Portugal montrent une dévaluation sous Jean $I$.

Keywords: coins, fineness, gold, silver, X-ray fluorescence.

Mots-clés : monnaies, titre, or, argent, FX.

\footnotetext{
* Dept. de Fisica/CCE, Universidade Estadual de Londrina, Cx.P. 6001, 86051-990 Londrina/PR, Brazil. (parreira@uel.br), (appoloni@uel.br)

** Museu Histórico Nacional,Rio de Janeiro/RJ, Brazil. (arjlobo@terra.com.br)

*** Centro Brasileiro de Pesquisas Físicas, Rio de Janeiro/RJ, Brazil. (scorza@cbpf.br)

**** Laboratoire du Centre de Recherche et de Restauration des Musées de France, UMR171 CNRS, France. (maria.guerra@culture.gouv.fr)
} 


\section{INTRODUCTION}

Among the analytical techniques used in the studies of cultural heritage objects, energy dispersive X-ray fluorescence (ED-XRF) is a very versatile one due to its portable configuration allowing in situ measurements. In situ experimental setups (Cesareo et al., 2007; Karydas, 2007) have been used to perform analyses in specific situations, such as in the case of large sculptures, frescos, paintings, etc., and to characterise metallic alloys, as well as several pigments. In the present work we used a handmade portable X-ray fluorescence system (pXRF) (Neiva et al., 2005; Appoloni et al., 2007) to analyse a set of gold, silver and billon coins from the collection of the Museu Histórico Nacional do Rio de Janeiro (MHN).

The analyses were carried out in the Numismatic Department of the MHN, and the aim of the study was to test the possibilities and limitations of this portable system for the determination of the coins' base alloys, and to verify whether the results obtained were consistent with historical facts. The assessment of this portable system was accomplished by comparing some of the compositions obtained in this work with the compositions obtained for the same coins with a fixed ED-XRF, as well as results from the literature on similar coins.
The base alloys were determined for coins struck during the Brasil Colônia period (from 1500 to independence, in 1822) and during the Dutch occupation (since the invasion of Bahia in 1624 to the insurrection of Pernambuco in 1654), as well as for Portuguese coins struck in Portugal during the reigns of Fernando I (1367 to 1383) and his successor João I (1383 to 1433). Figure 1 shows the pictures of a 4000 Réis gold coin (Brasil Colônia period, Bahia, 1695) and a silver coin of Real 'with FR' (Reign of Fernando I).

For the coins struck in Brazil, it was intended to verify whether a change in composition is visible with the moving of the royal mint from Bahia to Rio de Janeiro in 1698, to Pernambuco in 1700 , and to Rio de Janeiro in 1702 , before the discovery of gold in Minas Gerais, as well as to obtain the first results on the quality of the coins struck by the Dutch during the siege of Pernambuco, the so-called 'obsidional coins', the first coins bearing the name of Brazil.

Concerning the Portuguese coins, it was under Fernando I that a first reform of the Portuguese monetary system was observed. This reform, related to the war in Spain, is said to have resulted in a general debasement of the coins that was strengthened under João I, Fernando's successor. The analysis of coins struck under these two kings should allow verifying this assumption. For a first approach to those questions, a set of the coins and their dates of issue were selected in collaboration with the Numismatic Department of the MHN as follows.
Figure 1: (See colour plate) Images of the gold coin of 4000 Réis from the Brasil Colônia period (top) and silver coin from the reign of Fernando I, Portugal (bottom), showing the obverse and reverse sides, respectively.

Figure 1: (Voir planche couleur) Images de l'avers et du revers des monnaies d'or de 4000 Réis de la période Brasil Colônia (en haut) et d'argent du règne de Ferdinand I, Portugal (en bas).
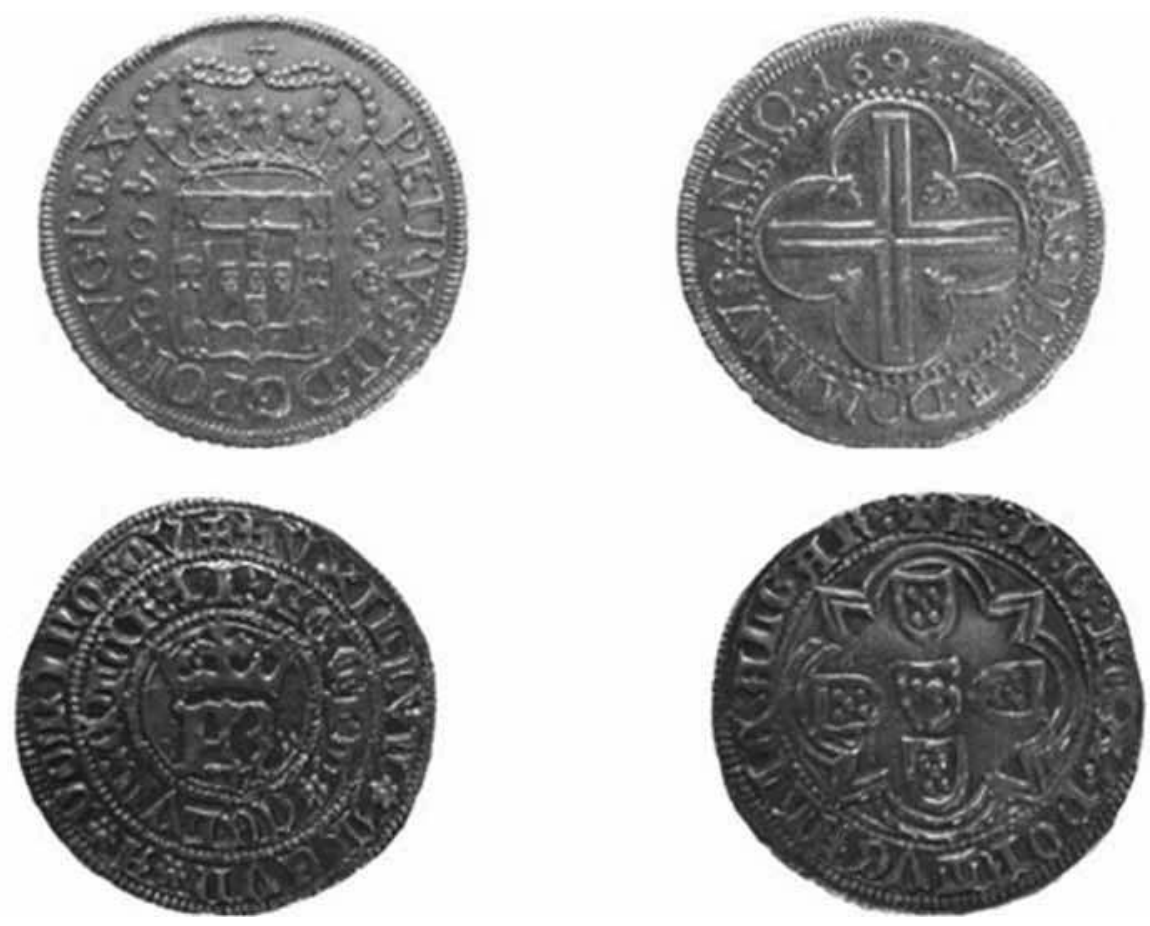


\section{Brasil Colônia period}

Four coins minted in Bahia (BA), Pernambuco (PE) and Rio de Janeiro (RJ) were analysed. One is a silver coin of 640 Réis, and three are gold coins of 4000 Réis, struck under Pedro II of Portugal.

\section{Dutch occupation period}

The obsidional coins, also called necessity currencies, were the first emissions minted in Brazilian territory with the inscription of the name Brasil (Vieira et al., 2007). These coins are rectangular plates. Three gold and three silver coins of different values were analysed.

\section{Fernando I}

Five silver coins of Real 'with FR', one coin of half Forte, and one coin of half Real 'with F' were analysed.

\section{João I}

For this period, a total of six billon coins were analysed: two coins of Real of three and half libras, one coin of half Real of ten soldos, one coin of a quarter Real Cruzado, and two coins of half Real Cruzado.

\section{EXPERIMENTAL}

The experimental setup consisted of a $7 \mathrm{~mm}^{2}$ Si-PIN detector (FWHM of $265 \mathrm{eV}$ for the $6.4 \mathrm{keV}$ Fe line) and a $95 \mathrm{mCi}$ annular radioactive source of ${ }^{238} \mathrm{Pu}$ (13.6 and 17.2 $\mathrm{keV}$ lines) for the excitation of the samples, arranged in a specific handmade system (PXRF-LFNA-01). The focus of the radiation beam strikes an area of approximately 180 $\mathrm{mm}^{2}$, while the coins have surfaces with areas ranging from 314 to $962 \mathrm{~mm}^{2}$; thus, the focus of the radiation beam covers between $57 \%$ and $19 \%$ of the coins' area, respectively.

For each piece, one measurement was carried out at the centre of the obverse and another one at the centre of the reverse, with $1000 \mathrm{~s}$ of excitation-detection time. The spectra were processed by AXIL (IAEA, free access software) and the results were expressed in weight percent. The Au and $\mathrm{Ag}$ contents were determined by using their $\mathrm{L} \alpha$ lines and $\mathrm{Cu}$ by using its $\mathrm{K} \alpha$ line.

The quantitative analysis was performed applying the well-known formula of the fundamental parameters to all the identified elements, without the matrix correction term. The results were scaled to the unit, equation 1 , to obtain relative values, based on Millazzo's work (Milazzo, 2004), with the difference that in the present case, instead of the pure massive standards for the determination of the elements' concentrations, experimental sensitivity curves, $S_{i}$, were used.

$$
W i=\frac{C_{i}}{\sum C_{n}}
$$

Where

$\mathrm{C}_{\mathrm{i}}$ is the concentration of the i element;

$\mathrm{W}_{\mathrm{i}}$ is the relative concentration of $\mathrm{i}$ element (\%).

Experimental sensitivities $S_{i}$ were obtained for each of the elements that constitute the gold and silver coins, employing MICROMATTER $^{\mathrm{TM}}$ standards (thin film standards of the elements and compounds for use in the calibration of X-ray fluorescence (XRF) equipment). The sensitivities obtained for the $\mathrm{K}$ and $\mathrm{L}$ lines are shown in Figures 2 and 3, respectively.

In the present work, the calculations were performed with no matrix corrections. This means no corrections for the self absorption of the characteristics X-rays by the matrix, and no corrections for the enhancement effects (fluorescence produced by heavier elements over lighter elements in the matrix). This approach does not significantly interfere with the quantification of the major elements $\mathrm{Au}$ and $\mathrm{Ag}$ of the coins, the main objective of this work, since they are present in high concentrations in the gold and silver coins, respectively, as can be seen in the following discussion of the results.

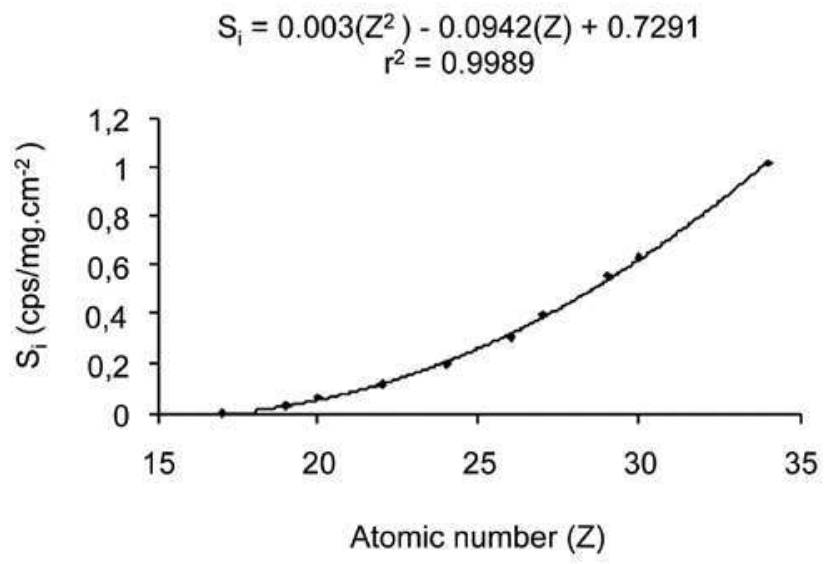

Figure 2: Calculated sensitivity for the $\mathrm{K}$ lines. Figure 2: Sensibilité calculée pour les lignes $K$. 


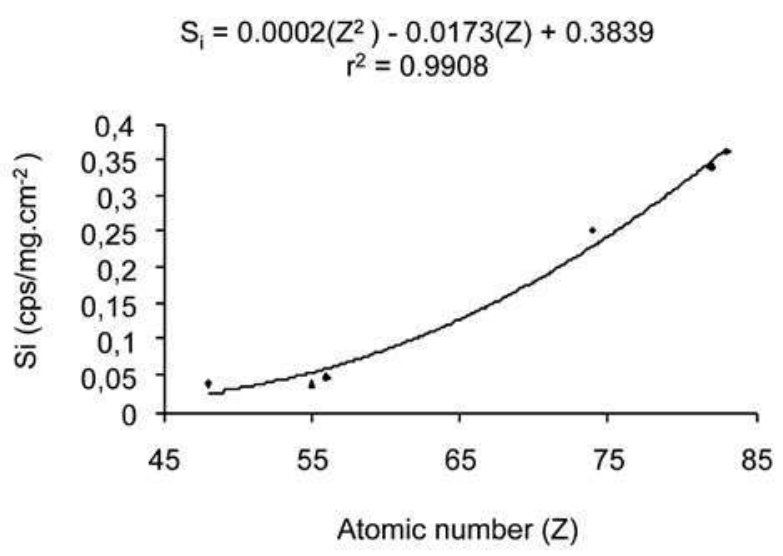

Figure 3: Calculated sensitivity for the L lines. Figure 3 : Sensibilité calculée pour les lignes L.

\section{RESULTS AND DISCUSSION}

Figures 4 and 5 show typical spectra of gold and silver coins where the $\mathrm{Cu}$ lines and the lines of the excitation source are also presented.

The average detection limits for the major elements $\mathrm{Au}$, $\mathrm{Ag}$ and $\mathrm{Cu}$ were $3.2 \%, 36.1 \%$, and $1.3 \%$ respectively for $\mathrm{Au}, \mathrm{Ag}$ and billon coins matrix.

The results obtained for the $\mathrm{Au}, \mathrm{Ag}$ and $\mathrm{Cu}$ contents are shown in Table 1. The reported results are the average of the two measurements performed on each coin, and its standard deviation. It was also possible to verify the occurrence of some other elements in the X-ray fluorescence spectra, such as $\mathrm{Ca}, \mathrm{Fe}, \mathrm{Hg}$ and $\mathrm{Pb}$, even if in much smaller concentrations, a matrix correction being necessary for their correct quantification.

Table 1 shows that all gold coins struck under the Dutch occupation have a homogeneous composition, containing on average $90.3 \% \mathrm{Au}, 8.3 \% \mathrm{Ag}$ and $0.6 \% \mathrm{Cu}$. The value of the coin is obtained by simply changing the gold weight. For example, for a coin of III Florins we could measure $1.87 \mathrm{~g}$, while for a coin of VI Florins we could measure $3.72 \mathrm{~g}$. The same situation was verified for the silver coins.

Measurements of $\mathrm{Ag}$ and $\mathrm{Au}$ contents for the coins struck during the Dutch occupation were also carried out using the fixed ED-XRF system of the Instituto Nacional de Tecnologia (INT). The values obtained for gold and silver contents, shown in Table 2, are on average $87.9 \%$ and $94.8 \%$, respectively, while the values determined with the portable system were $90.4 \%$ and $87.7 \%$. It can be seen that the results obtained with the PXRF system for Au in the coins of $I I I$ and $V I$ Florins show a difference of 2 to $4 \%$ from those reported by

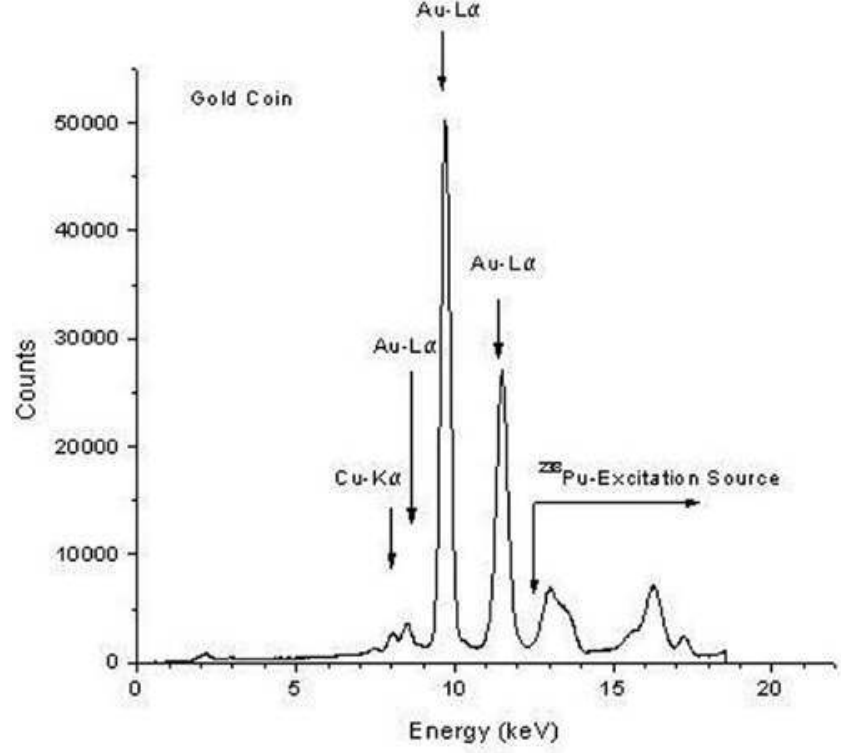

Figure 4: Typical spectrum obtained for gold coins. Figure 4 : Spectre typique des monnaies en or.

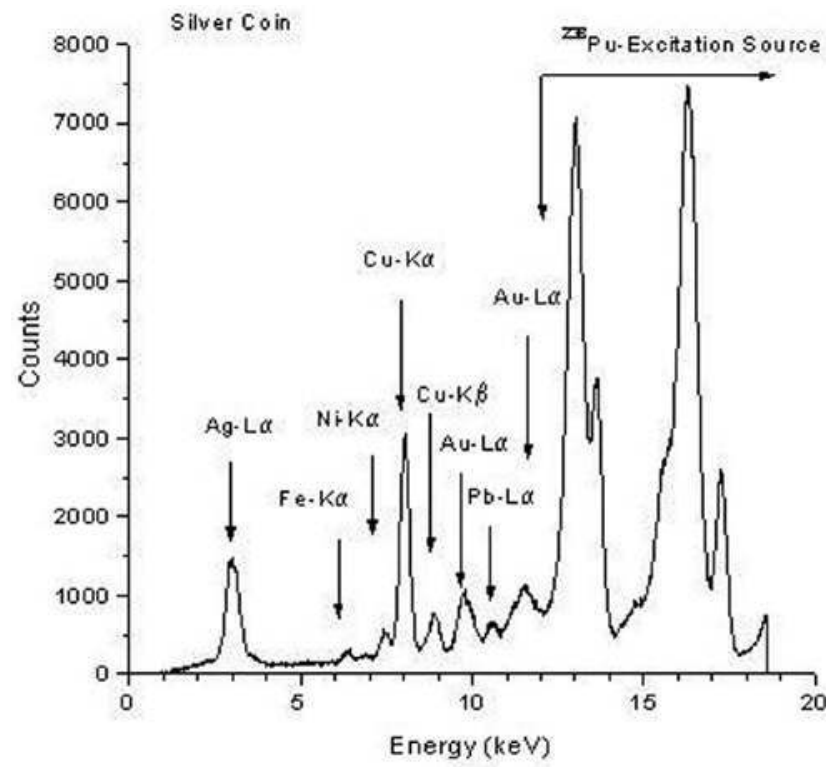

Figure 5: Typical spectrum obtained for silver coins. Figure 5 : Spectre typique des monnaies en argent.

the INT, while for the content of Ag in the coin of X soldos, the difference was about 7\%. This comparison shows that the simplified choice of no matrix correction was appropriate for the purpose of this work.

For the gold and silver coins struck during the Brasil Colônia period (1695-1702), an average of $96.8 \%$ and $80.5 \%$, for gold and silver contents, respectively, were 


\begin{tabular}{|c|c|c|c|c|c|c|c|}
\hline Origin & \multicolumn{2}{|l|}{ Denomination } & $\begin{array}{c}\text { Date of } \\
\text { issue }\end{array}$ & Weight g & $\mathrm{Au} \%$ & $\mathrm{Ag} \%$ & $\mathrm{Cu} \%$ \\
\hline \multirow{6}{*}{$\begin{array}{l}\text { Dutch occupation } \\
1645-1654\end{array}$} & \multirow{2}{*}{ III Florins } & 1 & 1646 & 1.83 & $89.6 \pm 0.3$ & $9.6 \pm 1.5$ & $0.49 \pm 0.04$ \\
\hline & & 2 & 1645 & 1.87 & $91.0 \pm 0.3$ & $7.8 \pm 1.7$ & $0.39 \pm 0.04$ \\
\hline & \multicolumn{2}{|l|}{ VI Florins } & 1645 & 3.72 & $90.5 \pm 0.3$ & $7.6 \pm 1.4$ & $0.80 \pm 0.04$ \\
\hline & \multirow{2}{*}{ XXXX Soldos } & 1 & 1654 & 12.04 & $0.70 \pm 0.04$ & $88.3 \pm 5.7$ & $10.0 \pm 0.1$ \\
\hline & & 2 & 1654 & - & $1.8 \pm 0.1$ & $86.7 \pm 5.2$ & $9.7 \pm 0.1$ \\
\hline & \multicolumn{2}{|l|}{ X Soldos } & 1654 & - & $0.5 \pm 0.1$ & $88.1 \pm 2.2$ & $10.9 \pm 0.1$ \\
\hline \multirow{4}{*}{$\begin{array}{l}\text { Brasil Colônia } \\
1695-1702\end{array}$} & \multicolumn{2}{|l|}{4000 Réis (PE) } & 1702 & 8.17 & $98.8 \pm 0.2$ & - & $0.67 \pm 0.02$ \\
\hline & \multicolumn{2}{|l|}{4000 Réis (BA) } & 1695 & 8.03 & $95.8 \pm 0.2$ & $1.7 \pm 0.5$ & $1.70 \pm 0.02$ \\
\hline & \multicolumn{2}{|l|}{4000 Réis (RJ) } & 1699 & 8.01 & $95.7 \pm 0.2$ & - & $2.19 \pm 0.03$ \\
\hline & \multicolumn{2}{|l|}{640 Reis (PE) } & 1701 & 18.39 & $0.4 \pm 0.1$ & $81 \pm 16$ & $17.1 \pm 0.1$ \\
\hline \multirow{7}{*}{$\begin{array}{l}\text { Portugal } \\
\text { King Fernando I } \\
1367-1383\end{array}$} & \multirow{5}{*}{\multicolumn{2}{|c|}{ Real with FR }} & - & 3.5 & $4.1 \pm 0.1$ & $84 \pm 14$ & $8.7 \pm 0.1$ \\
\hline & & & - & 3.47 & $1.20 \pm 0.04$ & $77 \pm 2$ & $21.0 \pm 0.1$ \\
\hline & & & - & 3.51 & $3.90 \pm 0.04$ & $79,8 \pm 1,5$ & $14.7 \pm 0.1$ \\
\hline & & & - & 3.55 & $1.6 \pm 0.1$ & $76 \pm 3$ & $21.2 \pm 0.1$ \\
\hline & & & - & 3.49 & $1.2 \pm 0.1$ & $82.5 \pm 2.1$ & $15.2 \pm 0.1$ \\
\hline & \multicolumn{2}{|l|}{$1 / 2$ Forte } & - & 1.64 & $0.7 \pm 0.1$ & $83.0 \pm 3.7$ & $14.6 \pm 0.1$ \\
\hline & \multicolumn{2}{|l|}{ 1/2 Real with F } & - & 1.84 & $1.1 \pm 0.1$ & $82.6 \pm 2.8$ & $15.1 \pm 0.1$ \\
\hline \multirow{6}{*}{$\begin{array}{l}\text { Portugal } \\
\text { King João I } \\
\text { 1383-1433 }\end{array}$} & \multirow{2}{*}{\multicolumn{2}{|c|}{ Real of $3 \frac{1}{2} 2$ libras }} & - & 2.8 & - & $14.4 \pm 0.8$ & $84.7 \pm 0.1$ \\
\hline & & & - & 1.84 & - & $2.7 \pm 0.6$ & $93.8 \pm 0.1$ \\
\hline & \multicolumn{2}{|l|}{$1 / 2$ Real of 10 soldos } & - & 1.9 & $0.20 \pm 0.04$ & $39.2 \pm 1.2$ & $59.9 \pm 0.1$ \\
\hline & \multicolumn{2}{|l|}{$1 / 4$ of Real cruzado } & - & 0.44 & - & $15.4 \pm 1.4$ & $83.7 \pm 0.2$ \\
\hline & \multirow{2}{*}{\multicolumn{2}{|c|}{ 1/2 Real cruzado }} & - & 2.18 & - & $10.4 \pm 0.9$ & $79.7 \pm 0.1$ \\
\hline & & & - & 1.89 & - & $6.8 \pm 0.7$ & $90.3 \pm 0.1$ \\
\hline
\end{tabular}

Table 1: Results obtained for $\mathrm{Au}$, $\mathrm{Ag}$ and $\mathrm{Cu}$ concentrations with pXRF.

Tableau 1 : Résultats obtenus pour les concentrations d'Au, d'Ag et de Cu parpFX.

\begin{tabular}{|c|c|c|c|c|c|}
\hline Origin & \multicolumn{2}{|l|}{ Denomination } & $\mathrm{Au} \%$ & $\mathrm{Ag} \%$ & $\mathrm{Cu} \%$ \\
\hline \multirow{4}{*}{$\begin{array}{c}\text { Dutch occupation } \\
1645-1654\end{array}$} & \multirow{2}{*}{ III Florins } & 1 & 88.09 & 10.75 & 0.45 \\
\hline & & 2 & 88.95 & 10.25 & 0.35 \\
\hline & \multicolumn{2}{|l|}{ VI Florins } & 86.82 & 12.08 & 0.61 \\
\hline & XXXX Soldos & 1 & 0.19 & 94.77 & 4.55 \\
\hline
\end{tabular}

Table 2: Results obtained with the INT stationary EDXRF system. Tableau 2 : Résultats obtenus avec le systèmes fixe de l'INT.

determined, while for the period from 1695 to 1698 , the values obtained by Guerra (2004) were $91.5 \%$ and $93.3 \%$, for coins minted in Bahia. When the results for $\mathrm{Cu}$ concentrations are compared, those obtained with PXRF vary from 0.7 to $2.2 \%$ for gold coins, while those obtained by Guerra (2004) vary from 0.9 to $1.7 \%$. These last results were obtained by PAA (Proton Activated Analysis) and TFNAA (Thermalised Fast Neutron Activated Analysis), which are absolute techniques with detection limits in the range of the ppm; however, both techniques use the induction of nuclear reactions and require the use of a particle accelerator to carry out the analysis.

Concerning the question of whether there was a change in composition of the coins struck in Brazil with the moving of the royal mint from Bahia to Rio de Janeiro in 1698, to Pernambuco in 1700 , and to Rio de Janeiro in 1702 , it can be observed in Table 1 that there is no difference between gold coins from 1695 and 1699, but that they are different from the gold coin from 1702, which has a greater $\mathrm{Au}$ content.
Regarding the coins struck in Portugal under Fernando I and João I, in the work of Norma Botelho Portugal (2000), it is assumed that due to large expenditures incurred because of wars with Castile, internal crises and conquest of the colonies in Africa, the debasement observed during the reign of João I was more important than the debasement observed under his predecessor Fernando I. This monetary debasement was experimentally demonstrated in this work and can be seen in Table 1. Hence, the average concentrations of $\mathrm{Ag}$ and $\mathrm{Cu}, 80.6 \%$ and $15.8 \%$, respectively, during the reign of King Fernando I, changed to $14.8 \%$ and $82.0 \%$, respectively, during the reign of King João I.

These results show the replacement of silver by copper in the monetary alloys used under the reign of King João I. For some of the analysed coins, it was also possible to verify the presence of $\mathrm{Ca}, \mathrm{Fe}, \mathrm{Hg}$ and $\mathrm{Pb}$, but the concentrations of these elements are close to the detection limits of our system and are strongly affected by the matrix, taking into account the expected higher deviations of pXRF systems (Kump et al., 2005). Therefore, the lack of precision in these measurements would also influence the accuracy of the results for the major elements $\mathrm{Au}$ and $\mathrm{Ag}$, since in this methodology the relative determination takes into account all the elements observed in the X-ray spectra. In addition to this, the presence of $\mathrm{Ca}$ is generally related to the cleaning processes performed in museums, and the Fe contents may be affected by many other phenomena than metallurgical processes. Only $\mathrm{Hg}$ and $\mathrm{Pb}$ could provide useful information on the metals and on the extraction techniques. 


\section{Conclusions}

The first results obtained with our portable XRF system for the measurement of major element $(\mathrm{Au}, \mathrm{Ag}$ and $\mathrm{Cu}$ ) concentrations in gold and silver monetary alloys showed a good agreement with the results obtained for the same coins by ED-XRF (Energy Dispersive $\mathrm{X}$-Ray Fluorescence) using a fixed system, as well as with those previously published for coins from the same period, analysed with nuclear activation techniques.

We must however denote that the advantage of this portable system is the fact that in situ measurements can be carried out with a relatively high analytical speed without moving the object from the museum to the laboratory. This portable system proved to be a viable technique in the study of coins, but the results may still be improved by considering matrix corrections, i.e. corrections for self-absorption and enhancement effects.

The more significant limitation of this system (and any portable system) is the fact that it is not possible to obtain reliable results for minor elements, due to the low activity of the radioactive source (or X-ray tube power of other pXRF systems). This limitation could, in part, be improved for future analysis by applying matrix correction.

The first results related to the quality of the $X$ soldos coin struck by the Dutch during the siege of Pernambuco were obtained, results which can be included among similar data for Ag and Au coins already measured (Vieira 2007). These coins represent the so-called 'obsidional coins', the first coins bearing the name of Brazil.

Results indicates that there was no change in the composition of the coins struck in Brazil with the moving of the royal mint from Bahia to Rio de Janeiro in 1698 and to Pernambuco in 1700 , but there was an increase in gold content after the returning of the royal mint to Rio de Janeiro in 1702.

The results obtained for the silver coins struck in Portugal in the $14^{\text {th }}-15^{\text {th }}$ century verified the assumption that a higher monetary debasement was observed during the reign of João I than during the reign of his predecessor, Fernando I.

\section{Acknowledgements}

We are grateful to LIN/CENA/USP for the loan of the ${ }^{238} \mathrm{Pu}$ source, to Centro Brasileiro de Pesquisas Fisicas for the financial support, and to the Museu Historico Nacional for providing the coins.

\section{References}

Appoloni, C.R., Blonski, M.S., Parreira, P.S. and Souza, L.A.C., 2007. Study of the pigments elementary chemical composition of a painting in process of attribution to Gainsborough employing a portable X-rays fluorescence system. Nuclear Instruments and Methods in Physics Research $A$ 580: 710-713.

Cesareo, R., Ferretti, M., Gigante, G.E., Guida, G., Moioli, P., Ridolfi, S. and GarCiA, C.R., 2007. The use of a European coinage alloy to compare the detection limits of mobile XRF systems. A feasibility study. X-Ray Spectrometry 36: 167-172.

GuERRA, M.F., 2004. The circulation of South American precious metals in Brazil at the end of the 17th century. Journal of Archaeological Science 31: 1225-1236.

KARYDAS, A.G., 2007. Application of a portable XRF spectrometer for the non-invasive analysis of museum metal artifacts. Annali di Chimica 97(7): 419-432.

Kump, P., NÈcemer, P. and RupniK, P., 2005. Development of the quantification procedures for in situ XRF analysis. Report IAEA-TECDOC-1456. Vienna.

Milazzo, M., 2004. Radiation applications in art and archaeometry X-ray fluorescence applications to archaeometry. Possibility of obtaining non-destructive quantitative analyses. Nuclear Instruments and Methods in Physics Research B 213: 683-692.

Neiva, A.C., Melo, H.G., Bendezú, H.R.P., Rizzutto, M.A., Tabacniks, M.H., Added, N., Appoloni, C.R., Parreira, P.S. and Cunha Lima, S., 2005. Caracterização espectroscópica das ligas e dos produtos de corrosão de peças metálicas do Museu de Arqueologia e Etnologia da USP, in Proceedings of $2^{2}$ Congresso Latino-Americano de Restauração de Metais, Rio de Janeiro, 25 to 28 July of 2005. Rio de Janeiro: Museu de Astronomia e Ciências Afins (MAST), 143-157.

Portugal, N.B., 2000. D. João I, Regência e reinado, in R.M.L. Vieira (ed.), Moedas Portuguesas da Época dos Descobrimentos na Coleção do Museu Histórico Nacional 1383-1583. Rio de Janeiro: Museu Histórico Nacional Press, 29-51.

Vieira, R.M.L., Guerra, M.F., Scorzelli, R.B., Souza Azevedo, I., Duttine, M. and Brito Pereira, C.E., 2007. Estudo preliminar de algumas moedas holandesas da coleção do Museu Histórico Nacional do Rio de Janeiro. Revista Brasileira de Arqueometria, Restauração e Conservação 1(6): 296-300. 